\title{
The cavernicolous genus Trogloniscus nomen novum, with descriptions of four new species from southern China (Crustacea, Oniscidea, Styloniscidae)
}

\author{
Stefano Taiti ${ }^{\mathrm{a} *}$ and Zhihong Xue ${ }^{\mathrm{b}}$ \\ ${ }^{a}$ Istituto per lo Studio degli Ecosistemi, Consiglio Nazionale delle Ricerche, Sesto Fiorentino, \\ Florence, Italy; ${ }^{b}$ Department of Entomology, College of Natural Resource and Environment, \\ South China Agricultural University, Wushan, Guangzhou, P.R. China
}

(Received 8 October 2012; final version received 15 November 2012; first published online 13 December 2012)

\begin{abstract}
The new name Trogloniscus is established for the terrestrial isopod genus Sinoniscus Schultz, 1995 (Styloniscidae), junior homonym of the fossil fish Sinoniscus Liu and Wang, 1978. Four new species of Trogloniscus from caves in Guangxi and Guizhou, southern China, are described: Trogloniscus hengliensis, Trogloniscus deharvengi, Trogloniscus clarkei and Trogloniscus trilobatus. The first two species are terrestrial and the last two are aquatic, collected in freshwater pools. In the family Styloniscidae, only one species (Thailandoniscus annae Dalens, 1989) from southern Thailand was previously known to occur in subterranean waters.
\end{abstract}

http://zoobank.org/urn:1sid:zoobank.org:pub:5F0AD578-2814-41E3-82D0-EE838 C5DD71C

Keywords: Crustacea; Isopoda; Oniscidea; Styloniscidae; Trogloniscus nomen novum; new species; cave-dwelling; Guangxi; Guizhou; China

\section{Introduction}

In recent years, several biospeleological investigations have been carried out in southern China, which have led to the discovery of a rich troglomorphic fauna including terrestrial isopods. At present, 14 species of Oniscidea are recorded from caves in Yunnan, Guangxi, Guizhou and Guangdong (Kwon and Taiti 1993; Schultz 1995; Taiti and Gruber 2008). This paper deals with species of Styloniscidae collected from caves in Guangxi and Guizhou during the Guangxi Integrated Forestry Development and Conservation Project (Deharveng et al. 2008), the Guangxi China Caves Expedition 2005 (Clarke 2007) and speleological research conducted by Iolanda Galletti, Centro Ibleo di Ricerche Speleoidrologiche, Ragusa, Italy.

At present, the family Styloniscidae includes nine genera in three subfamilies: Styloniscinae, Notoniscinae and Kuscheloniscinae. According to Vandel (1952), the subfamily Styloniscinae is characterized by body with smooth or tuberculated dorsum and epimera of pleonites $1-5$ reduced, so that the pleon is distinctly narrower than the pereon. It includes the following genera: Styloniscus Dana, 1853; Cordioniscus Graeve, 1914 (which may be a synonym of Styloniscus, see Schmalfuss and Erhard 1998);

\footnotetext{
*Corresponding author. Email: stefano.taiti@ise.cnr.it
} 
Clavigeroniscus Arcangeli, 1930; Indoniscus Vandel, 1952; Thailandoniscus Dalens, 1989 and Sinoniscus Schultz, 1995. Most probably also Pectenoniscus Andersson, 1960 has to be ascribed to this subfamily, according to its description (Andersson 1960). The species of Styloniscidae from caves in southern China described in this paper should belong to the genus Sinoniscus Schultz, 1995, but since this genus is a junior homonym of the fossil fish genus Sinoniscus Liu and Wang, 1978, a new replacement name is here proposed.

\author{
Abbreviations \\ IZCAS = Invertebrate Zoology Section of the Chinese Academy of Sciences, Beijing, \\ China \\ MNHN = Muséum National d'Histoire Naturelle, Paris, France \\ MZUF = Museo di Storia Naturale dell'Università, Sezione di Zoologia "La Specola", \\ Florence, Italy \\ SCAU = Department of Entomology, South China Agricultural University, Wushan, \\ Guangzhou, China \\ TMAG $=$ Tasmanian Museum and Art Gallery, Hobart, Tasmania, Australia \\ USNM = National Museum of Natural History, Smithsonian Institution, Washington, DC.
}

\title{
Systematic account
}

Family Styloniscidae

Genus Trogloniscus nom. n.

Synonym: Sinoniscus Schultz, 1995.

Type species: Sinoniscus cavernicolus Schultz, 1995 by present designation.

\section{Diagnosis}

Body slightly convex, unable to roll up into a ball, with pleon narrower than pereon. Sides of pleonites 4, 5 and uropodal protopods with visible gland pores. Cephalon with large lateral and frontal lobes, distinct frontal line, no suprantennal line. Pleonites 3-5 with epimera reduced, with small posterior points. Antennule of three articles, third article with a row of thickset apical aesthetascs. Antenna with flagellum of three clearly distinct articles; no visible aesthetascs. Right mandible with one free penicil; left mandible with two free penicils. Maxillule outer branch with 10-11 simple teeth and two setose stalks; inner branch with three penicils at apex. Maxilla with wide inner lobe and narrow outer lobe. Maxilliped endite with a segmented stout apical penicil. Pereopod dactylus with long, simple claw and apically bifid dactylar seta; pereopods 6 and 7 with setae and scales for the water conducting system. Uropodal protopod not grooved laterally; insertion of endopod proximal to that of exopod. Genital papilla lanceolate, more or less enlarged subapically and with acute apical part. Male pleopod 1 of Styloniscus type, that is with endopod of two articles with flagelliform distal article and strong muscular attachment.

\section{Etymology}

Greek Trōgle $=$ cave + Oniscus. Gender masculine. The name refers to the habitat where all the species of the genus have been collected. 


\section{Remarks}

The genus Sinoniscus was erected by Schultz (1995) for the species Sinoniscus cavernicolus collected in a cave near Guilin, Guangxi. The American author was certainly not aware that the genus Sinoniscus is a junior homonym of Sinoniscus Liu and Wang, 1978, a fossil fish genus (Palaeonisciformes) with type species Sinoniscus macrolepis from Xinjiang, China (Liu and Wang 1978). Since no other synonyms of Sinoniscus Schultz, 1995 are available, the new replacement name Trogloniscus is here established.

A new diagnosis of the genus is provided on the basis of the type species and the new species described herein. The genus is morphologically very similar to Styloniscus and Cordioniscus, from which it is distinguishable by the three clearly distinct flagellar articles of the antenna bearing no aesthetascs, the presence of a frontal line and absence of a suprantennal line. The suprantennal line was mentioned as present in the diagnosis of Sinoniscus by Schultz (1995), but the re-examination of the paratypes of Sinoniscus cavernicolus, even if not in a very good conservation state, showed that this line is actually absent.

\section{Trogloniscus cavernicolus (Schultz, 1995)}

Sinoniscus cavernicolus Schultz 1995: 202, figs 1-3; Hubbard and Wang 1997: 312; Schmalfuss 2003: 270.

Type material re-examined

China, Guangxi: $1 \bigcirc^{\prime}, 2$ $ᄋ$, 1 juv. paratypes, cave at Taiping Yan, N of Guilin, 1.VIII.1993, leg. D.A. Hubbard (USNM 267281).

\section{Distribution}

Known only from the type locality, Taiping Yan, N of Guilin, Guangxi.

\section{Trogloniscus hengliensis $\mathbf{n}$. sp.}

(Figures 1-5)

Material examined

China, Guangxi: $1 \sigma^{\top}$ holotype (IZCAS), $1 \sigma^{7}, 1$, 1 juv. paratypes (IZCAS), $1 \sigma^{7}$ paratype (SCAU), $3 \bigcirc^{\top} \sigma^{\prime}, 2$ 우 울 paratypes (MZUF), Hengli Dong, $593 \mathrm{~m}, 24^{\circ} 31^{\prime} 15.8^{\prime \prime} \mathrm{N}$, $107^{\circ} 02^{\prime} 35.1^{\prime \prime}$ E, Fengshan County, 5.XI.2005, leg. A.F. Clarke.

\section{Description}

Maximum dimensions: $\sigma^{7}, 10.5 \times 4.5 \mathrm{~mm}$; $q, 10.0 \times 4.5 \mathrm{~mm}$. Colourless, eyes absent. Body ovoidal with pleon distinctly narrower than pereon (Figure 1A). Dorsal surface smooth with scattered small triangular scale-seta (Figure 1B); large fields of gland pores on dorsal sides of pleonites 4 and 5, telson and uropodal protopods and exopods (Figure 1C). Cephalon (Figure 5A,B) with small quadrangular lateral lobes obliquely directed outwards and not protruding frontwards compared with profrons, no frontal lobe; frontal line distinct, medially bent down. Pereonite 1 with postero-lateral corners at right angle and posterior margin slightly sinuous; pereonites 2-7 with postero-lateral corners 

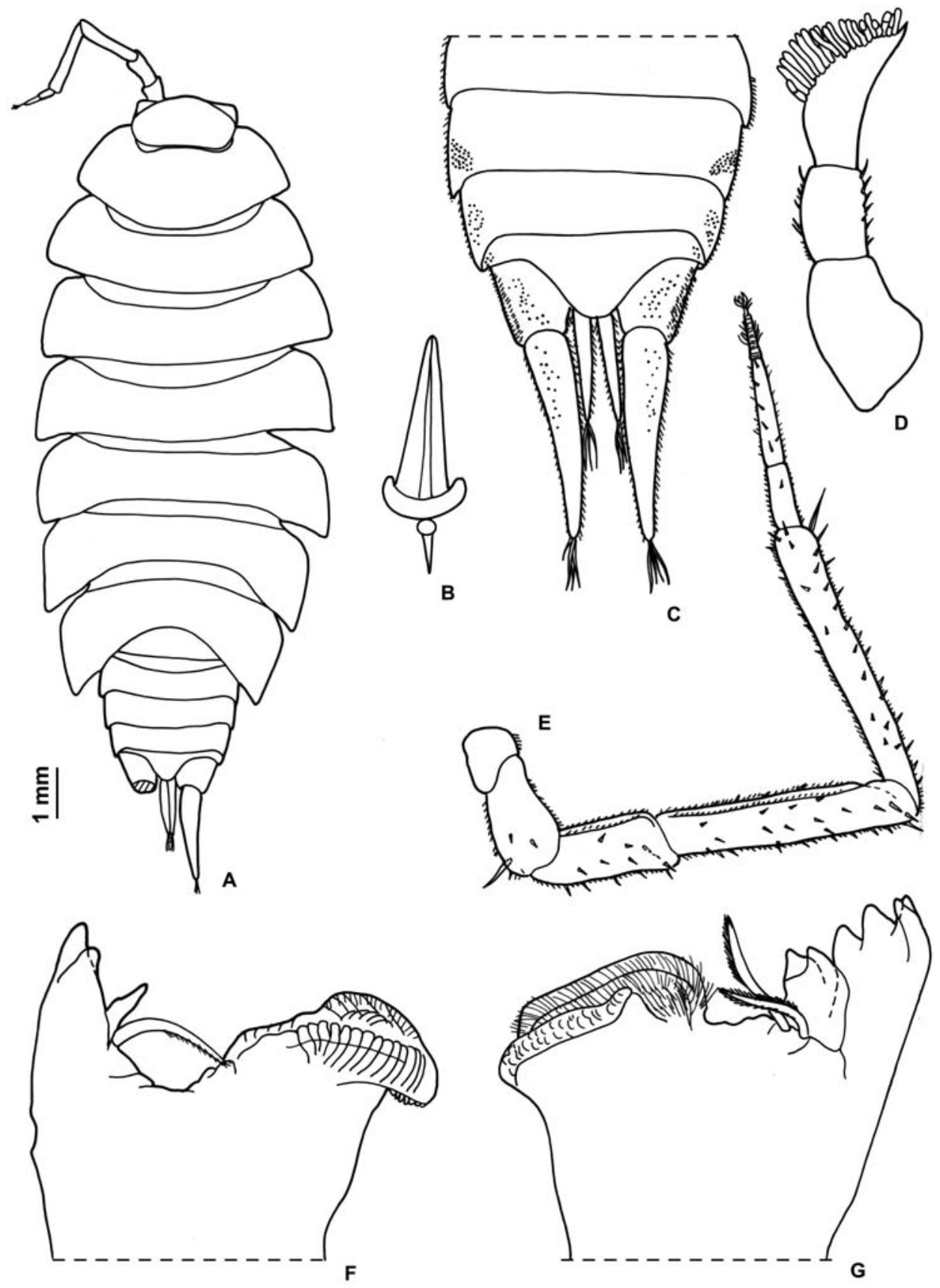

Figure 1. Trogloniscus hengliensis n. sp. $\sigma^{7}$ paratype from Hengli Dong: A: adult specimen in dorsal view; B: dorsal scale-seta; C: pleonites 3-5, telson and uropods; D: antennule; E: antenna; F: right mandible; G: left mandible. 

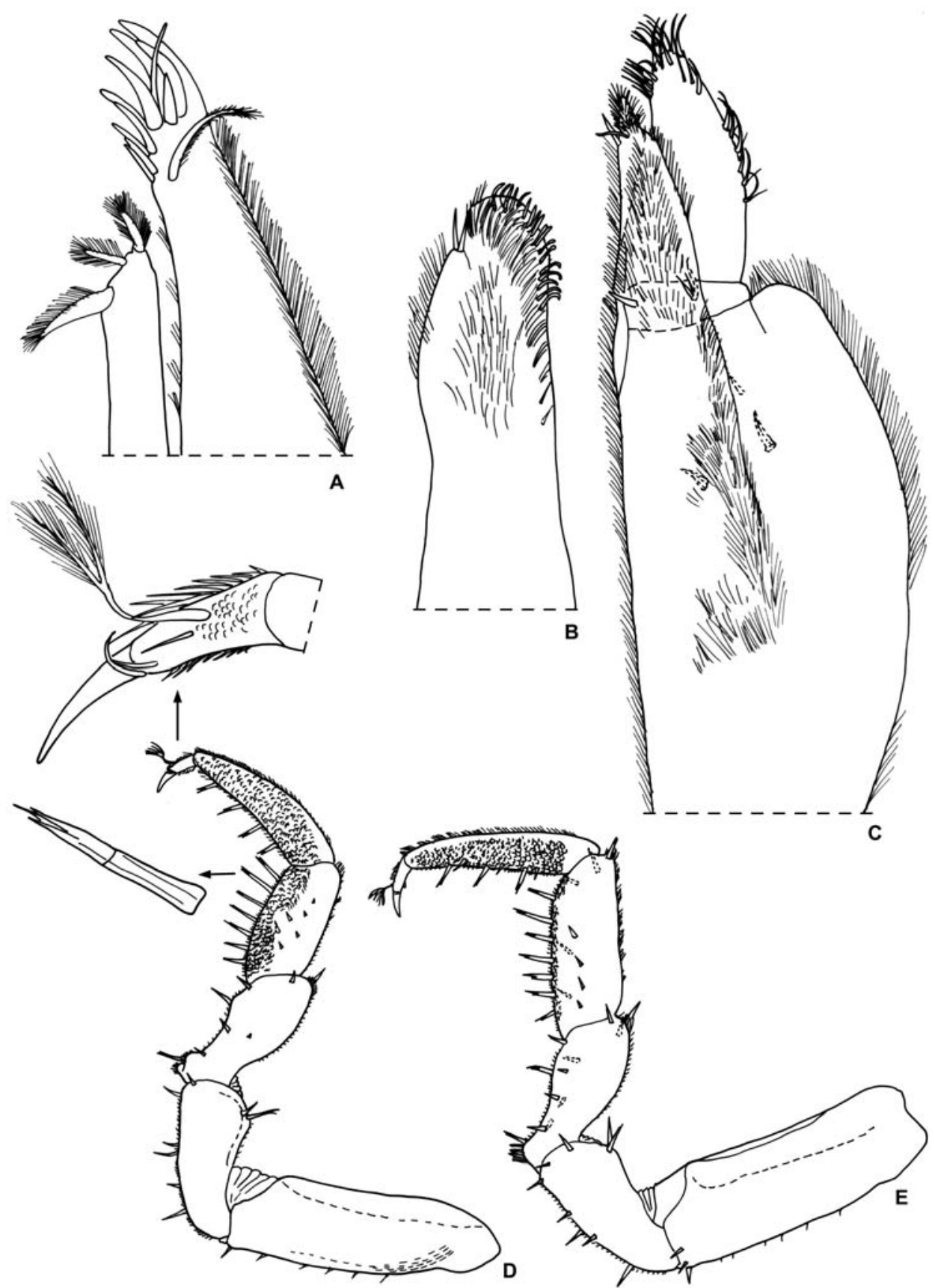

Figure 2. Trogloniscus hengliensis n. sp. $\bigcirc^{\top}$ paratype from Hengli Dong: A: maxillule; B: maxilla; C: maxilliped; D: pereopod 1; E: pereopod 2. 

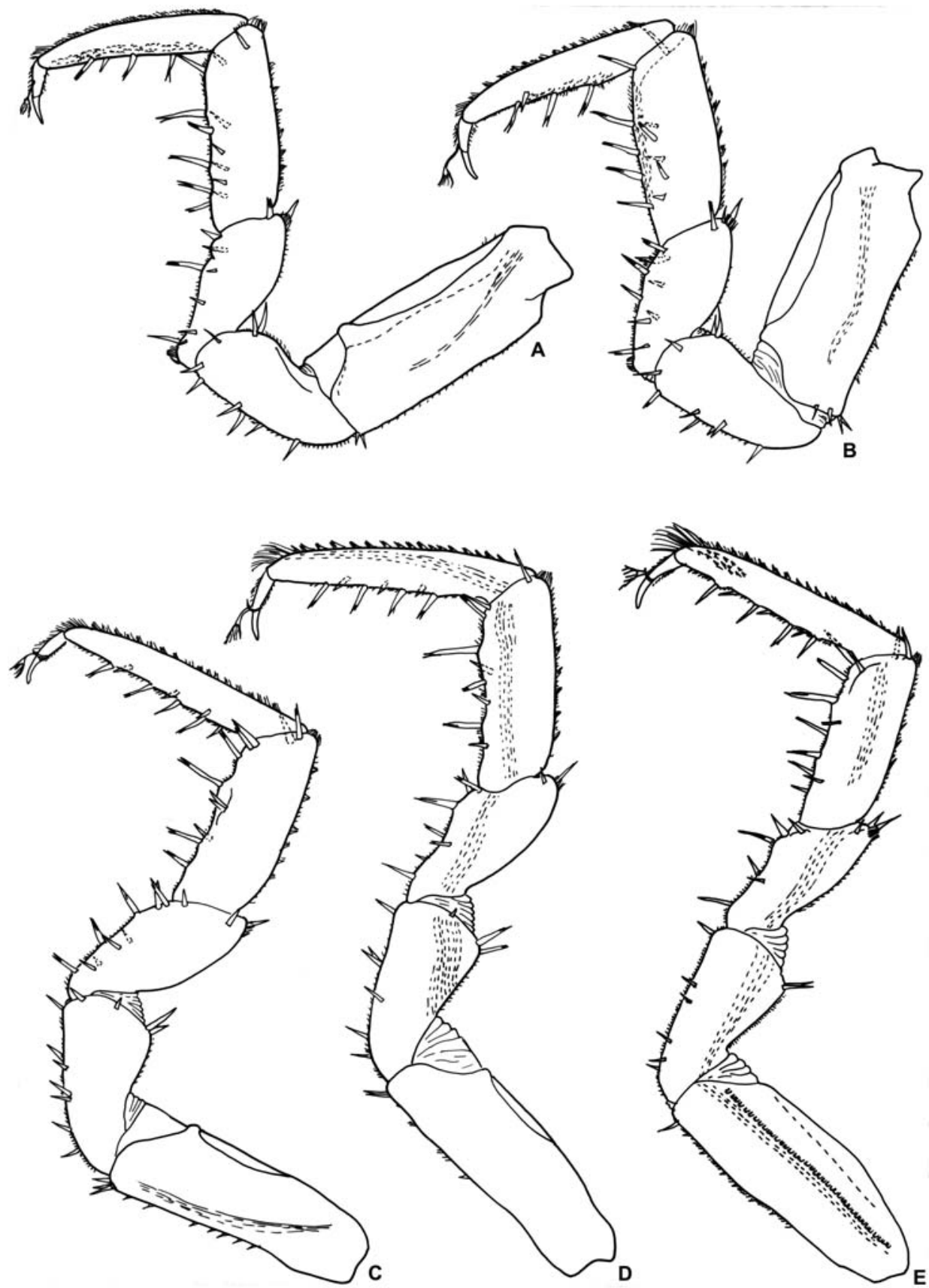

Figure 3. Trogloniscus hengliensis n. sp. $O^{7}$ paratype from Hengli Dong: A: pereopod 3; B: pereopod 4; C: pereopod 5; D: pereopod 6; E: pereopod 7.

progressively more acute; posterior margin of pereonite 7 regularly arched. Pleonites $1-3$ embedded in concavity of pereonite 7; posterior points of pleonites 3-5 very small, triangular, directed backwards (Figure 1C). Telson with concave sides and broadly rounded apex (Figure 1C). Antennule (Figure 1D) with third article bearing a small 


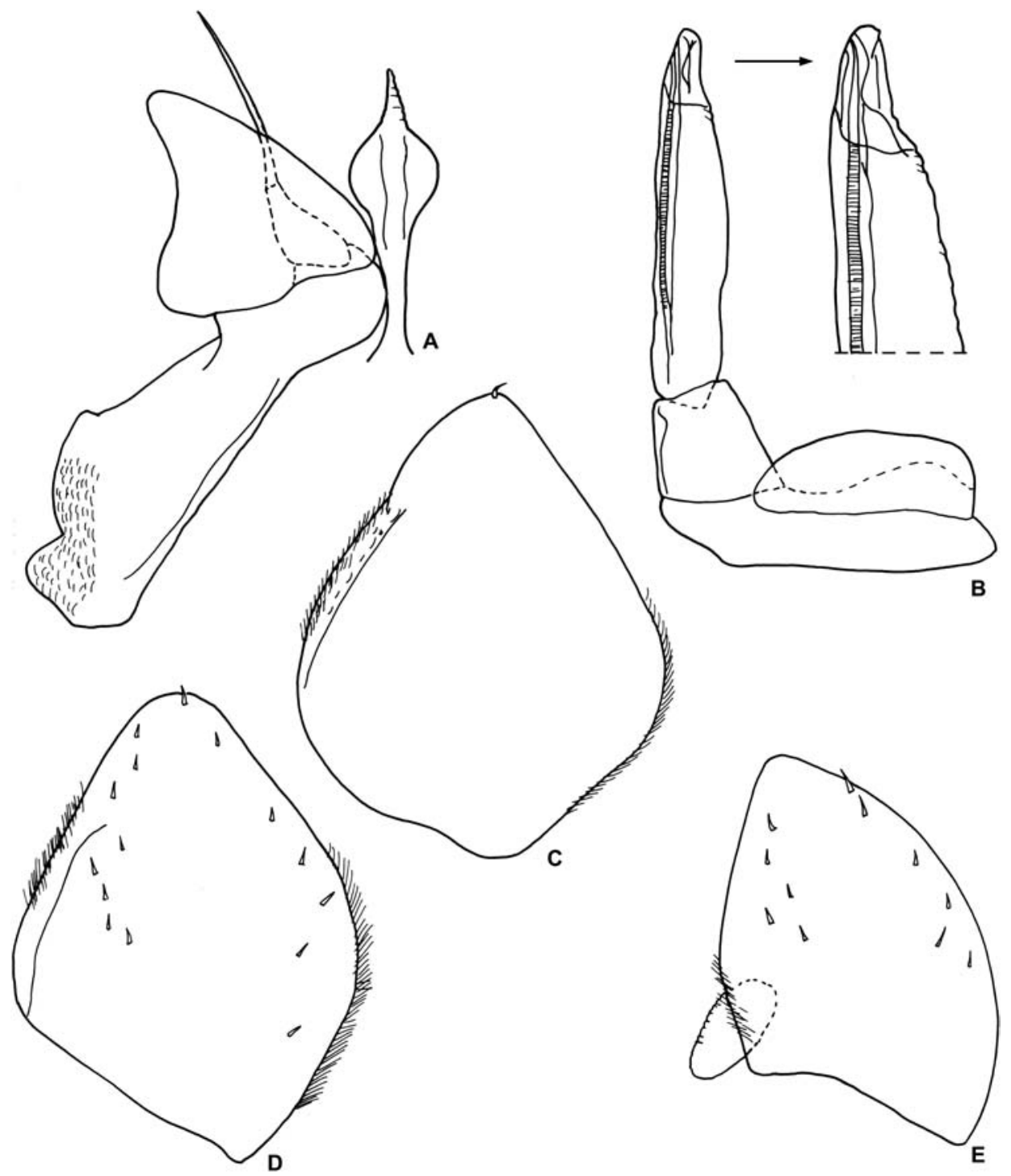

Figure 4. Trogloniscus hengliensis n. sp. $\sigma^{7}$ paratype from Hengli Dong: A: genital papilla and pleopod 1; B: pleopod 2; C: pleopod 3 exopod; D: pleopod 4 exopod; E: pleopod 5 exopod.

triangular point and a row of about 20 aesthetascs at apex. Antenna (Figure 1E) with fifth article of peduncle distinctly longer than flagellum; second articles of flagellum longer than first and third, third article much shorter. Mandibles (Figure 1F,G) as described in the generic diagnosis; no setae on molar process. Maxillule (Figure 2A) endite with proximal penicil distinctly longer than the two distal penicils. Maxilla (Figure 2B) with rounded inner lobe covered with long setae, more robust on disto-medial margin. Maxilliped (Figure 2C) with basis narrow, not distally enlarged; basal article of palp with two setae. Water conducting system on pereopod 6 ischium to propodus, and on pereopod 7 basis to 

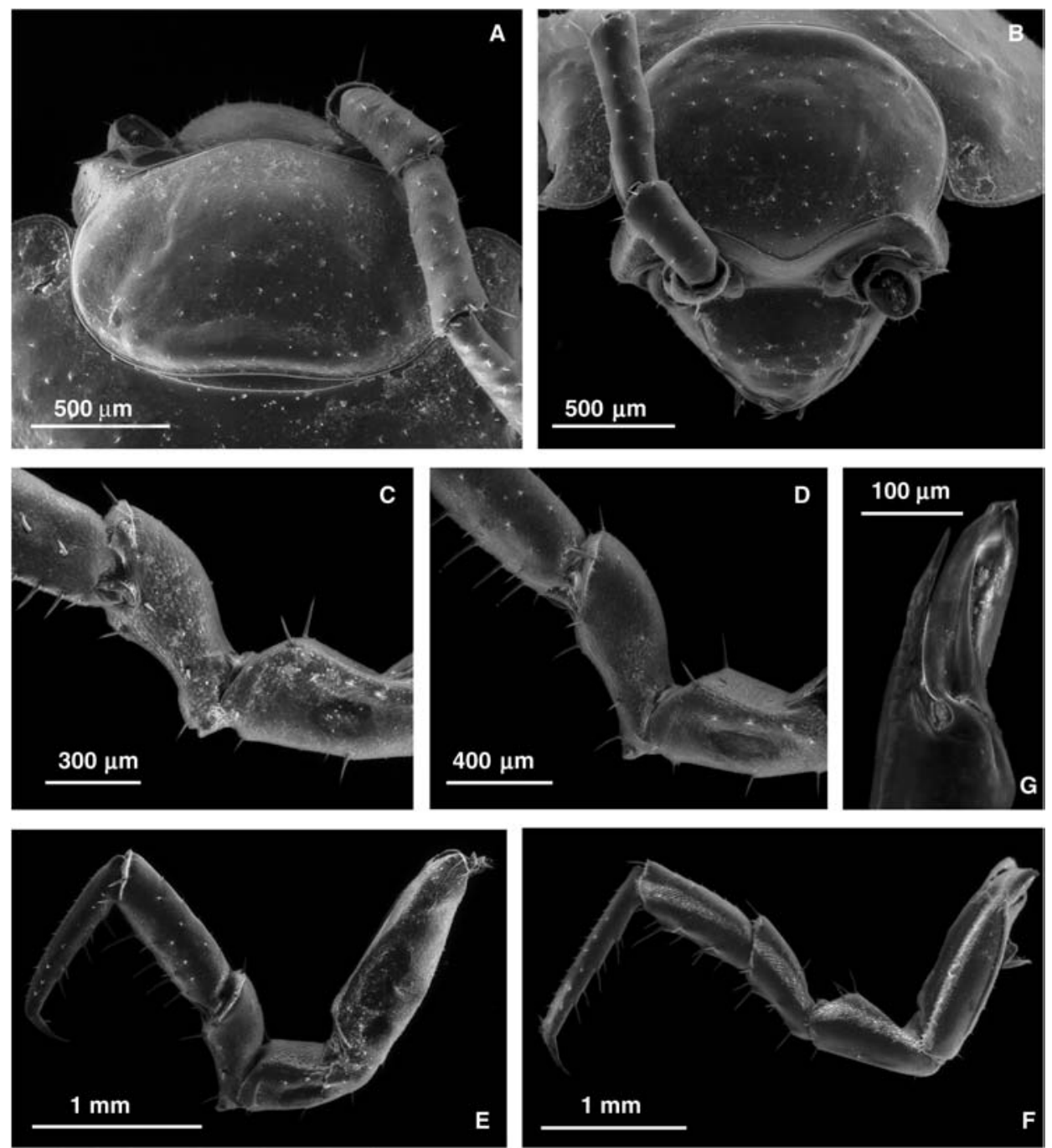

Figure 5. Trogloniscus hengliensis n. sp. $0^{7}$ paratype from Hengli Dong: A: cephalon, dorsal; B: cephalon, frontal; C: pereopod 1; D: pereopod 2; E: pereopod 3; F: pereopod 7; G: pleopod 2 endopod, distal part.

propodus; a tuft of long setae on the distal part of pereopods 6 and 7 (Figures 3D,E, 5F). Uropod (Figure 1C) with protopod about as long as wide; exopod about twice as long as endopod.

Male. Pereopods 1-3 and, to a lesser extent, 4 (Figures 2D,E, 3A,B, 5D-F) with a rounded lobe covered with thin setae at the base of merus, the lobe on pereopod 1 has a double apex. Pereopod 1 carpus and propodus with a large area covered with setae and scales. Pereopods 2 and, to a lesser extent, 3 and 4 with propodus covered with small scales. Pereopods 5-7 (Figures 3C-E, 5F) with no peculiar modifications; pereopod 7 ischium with sternal margin straight. Genital papilla (Figure 4A) elongated, swollen subapically with pointed apical part. Pleopod 1 (Figure 4A) exopod triangular with 
concave outer margin and narrowly rounded distal point; endopod with distal article flagelliform about twice as long as the basal article. Pleopod 2 (Figure 4B) exopod short and wide (about three times as wide as long), with broadly rounded distal margin; endopod thickset, with basal article quadrangular, distal article elongated, about three times as long as basal, with narrower distal part. Pleopod 3 exopod (Figure 4C) and pleopod 4 exopod (Figure 4D) similar in shape, rhomboidal, with a fringe of short setae on inner and outer margins. Pleopod 5 exopod (Figure 4E) triangular with convex outer margin and a semicircular lobe at medio-basal corner.

\section{Etymology}

The species name refers to Hengli Dong where the specimens have been collected.

\section{Remarks}

The new species is similar to Trogloniscus cavernicolus in the shape of male pleopods 1 and 2. It is readily distinguished in having the antennule with a larger number of apical aesthetascs (ca. 20 vs. 7) and the male pereopods $1-3$ with a distinct basal lobe on the sternal margin of the merus. A semicircular lobe at the base of the male pleopod 5 exopod, most probably used to hold and protect the tip of the pleopod 2 endopod, is present also in the following three new species and might be a generic character. Unfortunately it was not possible to check the presence of this character also in the male paratype of the type species Trogloniscus cavernicolus.

\section{Trogloniscus deharvengi n. sp.}

(Figures 6-8)

Sinoniscus sp. 2; Deharveng et al. 2008: 76, tab. 1.

\section{Material examined}

China, Guangxi: $1 \bigcirc^{\top}$ holotype (IZCAS), $4 \bigcirc^{\top} \sigma^{\top}, 3$ 우, 4 juvs paratypes (IZCAS), $4 \bigcirc^{\top} \sigma^{\top}$, 3 우 paratypes (MNHN), $8 \sigma^{\top} \sigma^{7}, 6$ 우 paratypes (MZUF), Dong Zai, $308 \mathrm{~m}$, Mulun Nature Reserve, 20.V.2007, leg. L. Deharveng team (sample \# CHIgx07-20-01); $3 \sigma^{7} \sigma^{7}$, 3 우 paratypes (SCAU), same locality, 25.X.2009, leg. M. Tian and A. Clarke (sample \# CHIgx07-20-01); 4 우 paratypes (IZCAS), Mashan Dong, $335 \mathrm{~m}$, Mulun Nature Reserve, 19.V.2007, leg. L. Deharveng, A. Bedos, Y.B. Li and W.B. Xu (sample \# CHIgx07-19-01); $6 \bigcirc^{\top} \bigcirc^{7}, 8$ 우 paratypes (MZUF), same locality and date, leg. F. Bréhier (sample \# CHIgx07-19-02); $5 \bigcirc^{7} \sigma^{7}, 2$ O paratypes (SCAU), same locality, 27.X.2009, leg. M. Tian, G.F. Wei, F. Zhang and A. Clarke (sample \# CHIgx09-018); 1 ○, 3 우 paratypes (MZUF), Gui Dong 2, 620 m, Mulun Nature Reserve, 18.V.2007, leg. F. Bréhier (sample \# CHIgx07-18-20); $3 \sigma^{7} \sigma^{7}, 2$ 우 paratypes (MZUF), Gang Lai Dong, Mulun Nature Reserve, 12.III.2005, L. Deharveng and A. Bedos (sample \# CHIgx05-075); $3 \bigcirc^{\top} \bigcirc^{\top}, 5$ 우 paratypes (SCAU), Dongtu Dong, Mulun Nature Reserve, 28.X.2009, leg. M. Tian, Y.B. Li, G.F. Wei and L.T. Wei (sample \# CHIgx09-019); 5 ○ $\sigma^{\top}, 2$ o 2 paratypes (IZCAS) $5 \sigma^{\top} \sigma^{\top}, 2+q$ paratypes (SCAU), Ganxiao Dong, Mulun Nature Reserve, 7.XI.2009, leg. M. Tian, Y.B. Li, G.F. Wei and L.T. Wei (sample \# 


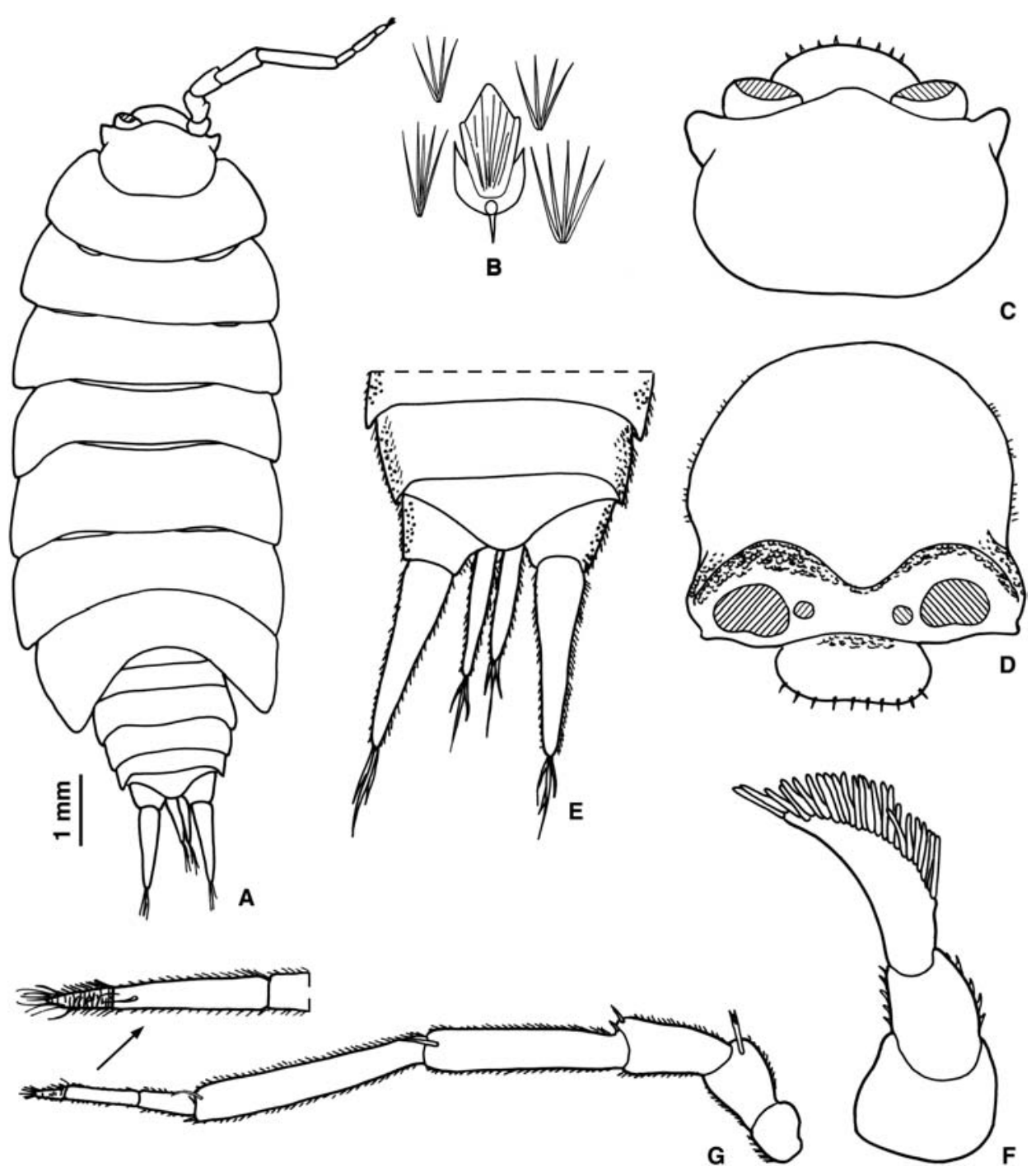

Figure 6. Trogloniscus deharvengi n. sp. $\bigcirc^{7}$ paratype from Dong Zai: A: adult specimen in dorsal view; B: dorsal scale-seta and cuticular structures; C: cephalon, dorsal; D: cephalon, frontal; E: pleonites 4 and 5, telson and uropods; F: antennule; G: antenna.

CHIgx09-087); $4 \bigcirc^{\top} \sigma^{\top}, 6$ 우 paratypes (IZCAS), $4 \sigma^{\top} \sigma^{\top}, 5$ 우 paratypes (SCAU), Xia Dong \& Shang Dong, Mulun Nature Reserve, 3.XI.2009, leg. M. Tian, G.F. Wei, L.T. Wei, Z.J. Yu and E. Chia (sample \# CHIgx09-074); $5 \sigma^{7} \sigma^{7}, 2$ 우 paratypes (IZCAS), $4 \sigma^{\top} \bigcirc^{\top}, 2$ q $q$ paratypes (SCAU), Houka Dong, Mulun Nature Reserve, 2.XI.2009, leg. M. Tian, Y.B. Li, G.F. Wei and L.T. Wei (sample \# CHIgx09-054); 1 ○’, 1 \& paratypes (SCAU), Hong Dong, Mulun Nature Reserve, 13.II.2009, leg. M. Tian, L. Deharveng, J. Liu and T. Whitten (sample \# CHIgx09-001). Guizhou: $12 \bigcirc^{\top} \sigma^{\top}, 12$ 우 (IZCAS), 12 $\bigcirc^{\top} \sigma^{\top}, 12$ 우 (SCAU), Dongge Dong, Maolan Nature Reserve, 26.VII.2009, leg. Z. Xue and C. Chen. 


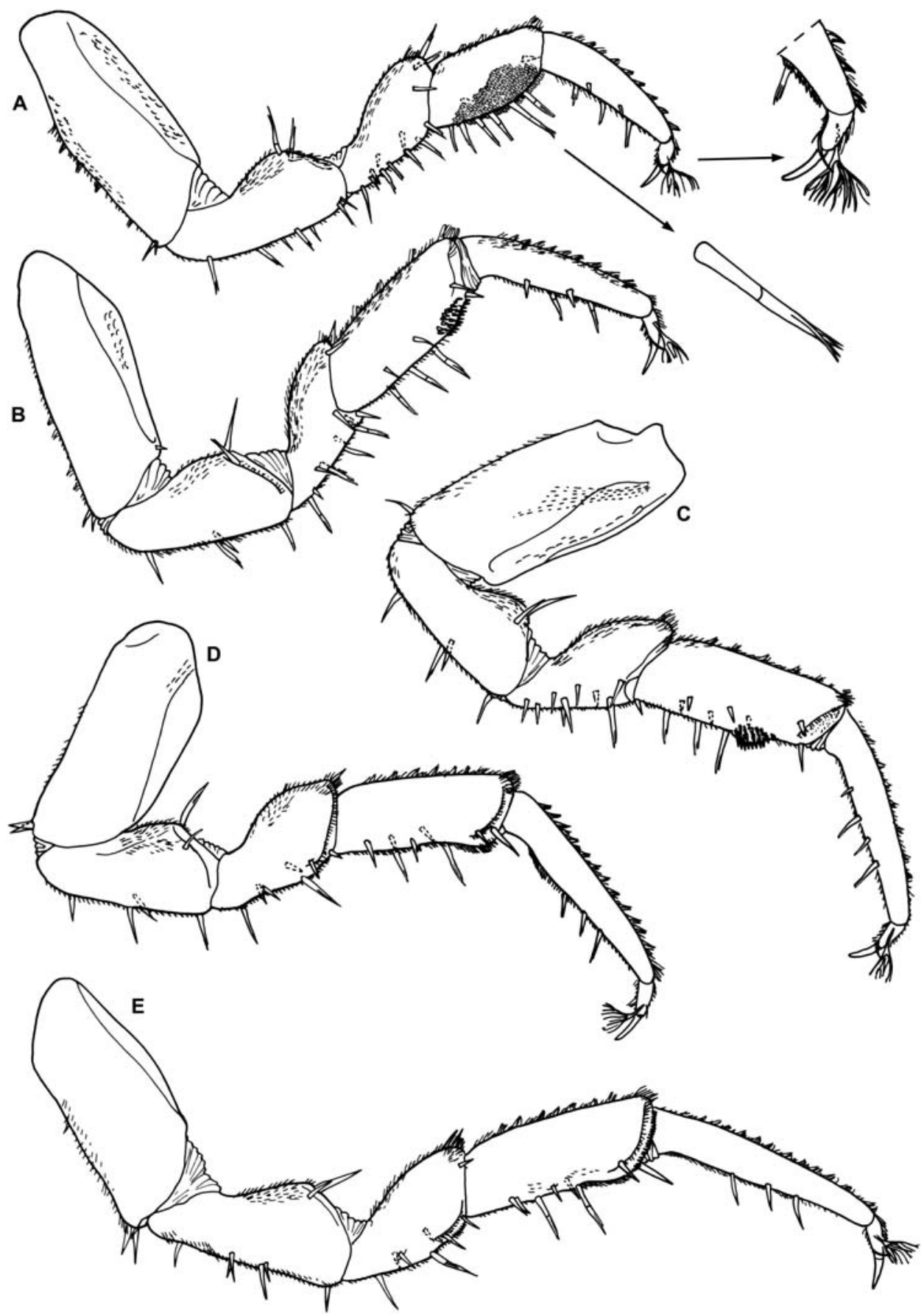

Figure 7. Trogloniscus deharvengi n. sp. $\bigcirc^{7}$ paratype from Dong Zai: A: pereopod 1; B: pereopod 2; C: pereopod 3; D: pereopod 4; E: pereopod 5. 


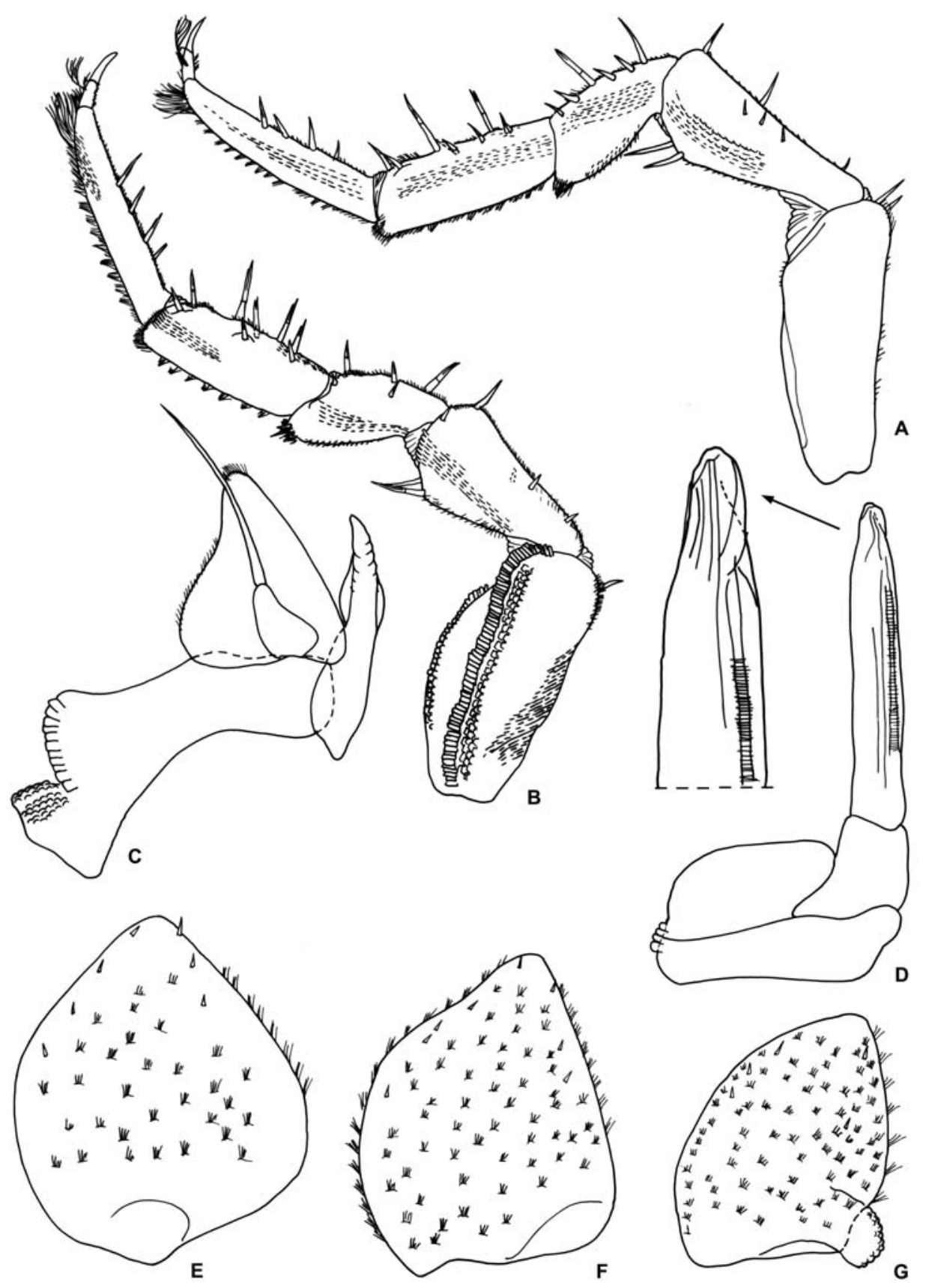

Figure 8. Trogloniscus deharvengi n. sp. $\sigma^{7}$ paratype from Dong Zai: A: pereopod 6; B: pereopod 7; C: genital papilla and pleopod 1; D: pleopod 2; E: Pleopod 3 exopod; F: pleopod 4 exopod; G: pleopod 5 exopod. 


\section{Description}

Maximum dimensions: $\sigma^{7}, 10.0 \times 4.0 \mathrm{~mm}$;,, $10.5 \times 4.0 \mathrm{~mm}$. Colourless, eyes absent. Body shape as in Figure 6A. Dorsal surface smooth covered with tufts of 4 or 5 small thin setae and scattered small rhomboidal scale-setae (Figure 6B); ventral surface of pleopods 1-3 exopods with similar tufts of small setae; dorsal sides of pleonites 4 and 5 and uropodal protopods with gland pores (Figure 6E). Cephalon (Figure 6C,D) with small triangular lateral lobes obliquely directed outwards; obtuse frontal lobe slightly protruding frontwards compared with lateral lobes; frontal line distinct, medially bent down. Pereonites 1-3 with postero-lateral corners rounded and posterior margin straight; pereonites 4-7 with postero-lateral corners progressively more acute; posterior margin of pereonite 7 regularly arched. Pleonites $3-5$ with posterior points very small, triangular, directed backwards (Figure 6E). Telson with slightly concave sides and broadly rounded apex (Figure 6E). Antennule (Figure 6F) with first article shorter than second and third; third article with a row of about 25 long aesthetascs on medial margin. Antenna (Figure 6G) with fifth article of peduncle distinctly longer than flagellum; second article of flagellum longer than first and third, third article much shorter. Buccal pieces as in Trogloniscus hengliensis. Water conducting system on pereopod 6 ischium to propodus, and on pereopod 7 basis to propodus; a tuft of long setae on the distal part of pereopods 6 and 7 (Figure 8A,B). Uropod (Figure 6E) with protopod about as long as wide; endopod about $2 / 3$ as long as exopod.

Male. Pereopod 1 (Figure 7A) carpus covered with scales and setae near sternal margin. Pereopod 2 (Figure 7B) carpus with a setose area on distal part near sternal margin. Pereopod 3 (Figure 7C) carpus with a hump covered with scales on distal sternal margin. Pereopods 4 and 5 (Figure 7D,E) carpus with sternal margin slightly concave in the distal part, covered with scales. Pereopods 6 and 7 (Figure 8A,B) ischium with sternal margin straight. Genital papilla (Figure 8C) elongated, slightly swollen subapically. Pleopod 1 (Figure 8C) exopod triangular with slightly concave outer margin covered with fine setae and narrowly rounded distal point; endopod with distal article flagelliform about three times as long as basal article. Pleopod 2 (Figure 8D) exopod about twice as wide as long, with broadly rounded distal margin; endopod thickset, with basal article quadrangular, distal article elongated, more than three times as long as basal, with distal part slightly narrower and rounded apex. Pleopod 3 exopod (Figure 8E) rhomboidal. Pleopod 4 exopod (Figure 8F) trapezoidal. Pleopod 5 exopod (Figure 8G) triangular with convex outer margin and a semicircular lobe at medio-basal corner.

\section{Etymology}

The species is named after our colleague and friend Dr Louis Deharveng, Paris, who collected part of the material included in this paper.

\section{Remarks}

Trogloniscus deharvengi differs from both Trogloniscus cavernicolus and Trogloniscus hengliensis in having the dorsal body surface covered by tufts of thin setae, antennule with a larger number of aesthetascs, modifications on the carpus of the male pereopods 2-5 and thicker distal part of male pleopod 2 endopod. It also differs from Trogloniscus hengliensis in having rhomboidal instead of triangular dorsal scale-setae and in lacking the basal lobe on the merus of the male pereopods $1-3$. 


\section{Trogloniscus clarkei n. sp.}

(Figures 9-12)

\section{Material examined}

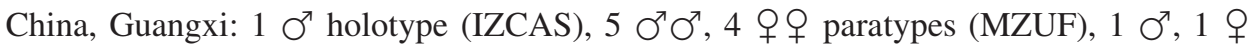
paratypes (TMAG), Dashan Dong (Big Mountain Cave), $670 \mathrm{~m}, 24^{\circ} 18^{\prime} 20.8^{\prime \prime} \mathrm{N}$, $107^{\circ} 00^{\prime} 47.3^{\prime \prime} \mathrm{E}$, near Dalue Village, Bama County, high upper level seepage fed gour pools with fine grit substrate and guano flecks, dark zone $1.5 \mathrm{~km}$ from entrance, 20.X.2005, leg. A. Clarke; $2 \bigcirc^{7} \sigma^{\top}, 4+q$ paratypes (IZCAS), $1 \bigcirc^{\top}, 1$ q paratypes (SCAU), same data, lower level trickle fed gour pools with silty substrate and pieces of bat guano near cave sump, 350-400 m into cave; $1 \bigcirc^{\prime}, 3$ q $q$ paratypes (MZUF), Jiang Zhou system (via Long Huai entrance), $501 \mathrm{~m}, 24^{\circ} 20^{\prime} 45.0^{\prime \prime} \mathrm{N}, 106^{\circ} 59^{\prime} 12.8^{\prime \prime} \mathrm{E}$, about $4.3 \mathrm{~km}$ NE of the township of Jiang Zhou, $10 \mathrm{~km}$ from Pingli, Fengshan County, pool with sandy silt substrate, in dark zone 150-200 m into cave, 31.X.2005, leg. A. Clarke.

\section{Description}

Maximum dimensions: $\sigma^{7}, 18.0 \times 6.5 \mathrm{~mm}$; $q, 15.5 \times 6.0 \mathrm{~mm}$. Colourless, eyes absent. Body elongated, with pleon distinctly narrower than pereon (Figure 9A). Dorsal surface smooth with sparse pointed scale-setae (Figure 9B); a few gland pores on dorsal sides of pleonites 4 and 5, telson and uropodal protopod (Figure 11D,E). Cephalon (Figure $11 \mathrm{~A}-\mathrm{C}$ ) with large quadrangular lateral lobes with rounded apices and obliquely directed outwards; a triangular frontal lobe, slightly excavated dorsally, directed frontwards, clearly protruding compared with the lateral lobes; frontal line straight at sides and pointing down in the middle. Pereonites 1-4 with postero-lateral corners rounded, posterior margin straight; pereonites 5-7 with postero-lateral corners progressively more acute, posterior margin regularly concave. Pleonites 1-3 with posterior points very small, directed backwards (Figure 11D,E). Telson with concave sides and broadly rounded apex (Figure 11D). Antennule (Figure 9C) with articles subequal in length; third article with a triangular point and a row of about nine short and thickset aesthetascs at apex. Antenna (Figure 9D) with fifth article of peduncle distinctly longer than flagellum; first article of flagellum slightly longer than second, third article much shorter. Mandibles (Figure 9E,F) with a small penicil on molar process. Maxillule (Figure 9G) endite with distal and basal setae distinctly longer than middle setae. Maxilla (Figure 9H) with a fringe of long strong setae on disto-medial margin. Maxilliped (Figure 10A) with distal part of basis much wider than basal part; apical penicil of endite short and stout; basal article of palp with seven setae. Waterconducting system on pereopod 6 ischium to propodus (Figure 12B) and on pereopod 7 basis to merus (Figure 12C,D). Uropod (Figure 11D) with protopod wider than long; exopod slightly longer than endopod.

Male. Pereopods 1-4 (Figures 11F,G, 12A) subchelate, with carpus enlarged. Pereopod 1 merus, carpus and propodus with a large area covered by small scales. Pereopods 6 (Figure 12B) and 7 (Figure 12C) ischium with a large depression along the whole sternal margin. Genital papilla (Figure 10B) pointed and slightly swollen subapically. Pleopod 1 exopod (Figure 10C) triangular with slightly concave outer margin covered with fine setae and rounded distal point equipped with a strong seta; endopod with distal article flagelliform about twice as long as basal article. Pleopod 2 exopod (Figure 10D) short and wide (about three times as wide as long); endopod 


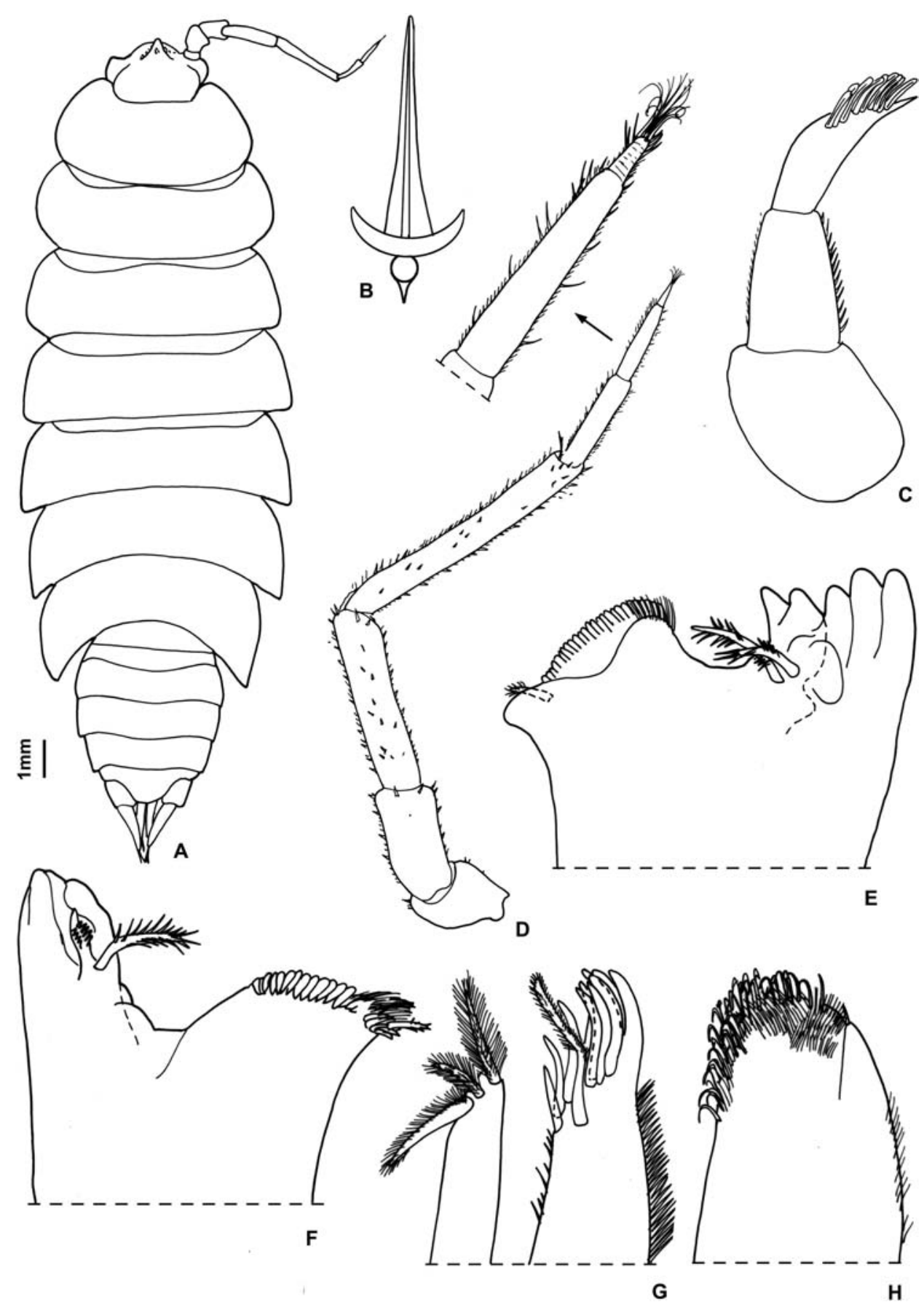

Figure 9. Trogloniscus clarkei $\mathbf{n}$. sp. $\bigcirc^{7}$ paratype from Dashan Dong: A: adult specimen in dorsal view; B: dorsal scale-seta; C: antennule; D: antenna; E: left mandible; F: right mandible; G: maxillule; H: maxilla. 


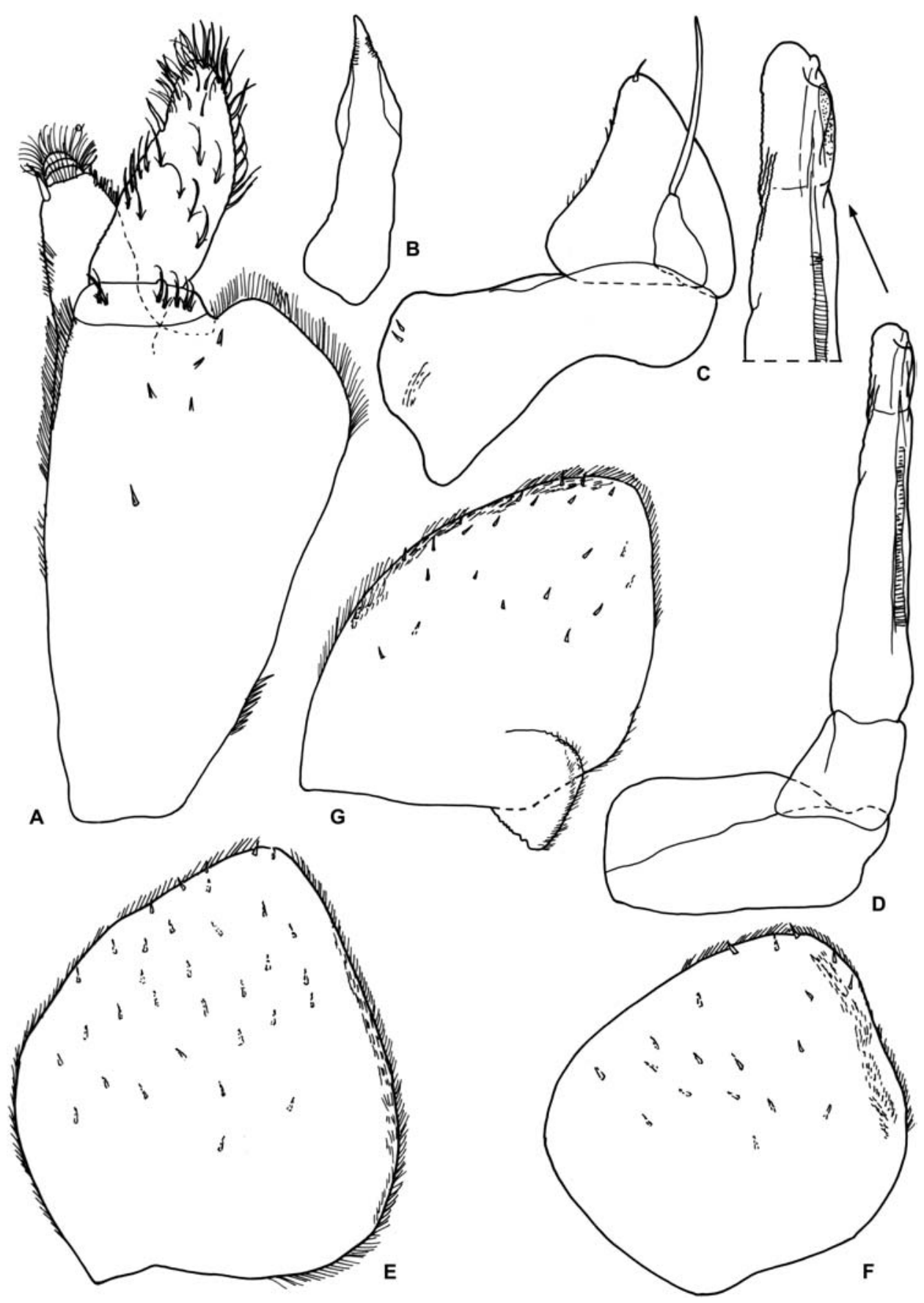

Figure 10. Trogloniscus clarkei n. sp. $\bigcirc^{7}$ paratype from Dashan Dong: A: maxilliped; B: genital papilla; C: pleopod 1; D: pleopod 2; E: pleopod 3 exopod; F: pleopod 4 exopod; G: pleopod 5 exopod. 

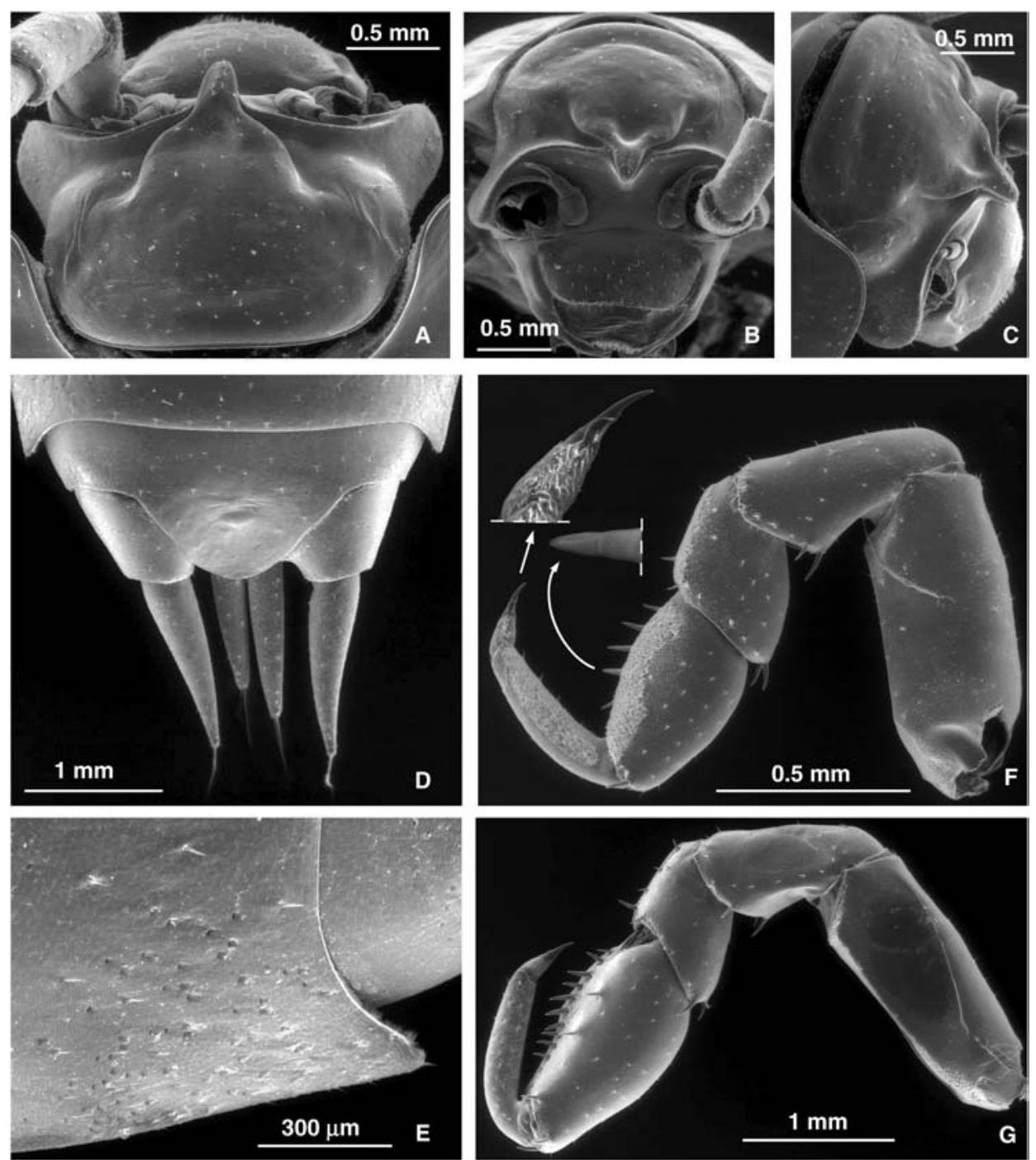

Figure 11. Trogloniscus clarkei n. sp. $\bigcirc^{\top}$ paratype from Dashan Dong: A: cephalon, dorsal; B: cephalon, frontal; C: cephalon, lateral; D: pleonite 5, telson and uropods; E: left epimeron of pleonite 5 showing gland pores; F: pereopod 1; G: pereopod 2.

thickset throughout its whole length, basal article quadrangular, distal article about four times as long as basal, rounded apex. Pleopods 3 (Figure 10E) and 4 (Figure 10F) exopods quadrangular with a fringe of short setae on margins. Pleopod 5 exopod (Figure 10G) triangular with fine setae on outer and medial margins; a quadrangular lobe on medio-basal corner.

\section{Etymology}

The species is named after Arthur F. Clarke, Hobart, Tasmania, who collected the specimens. 

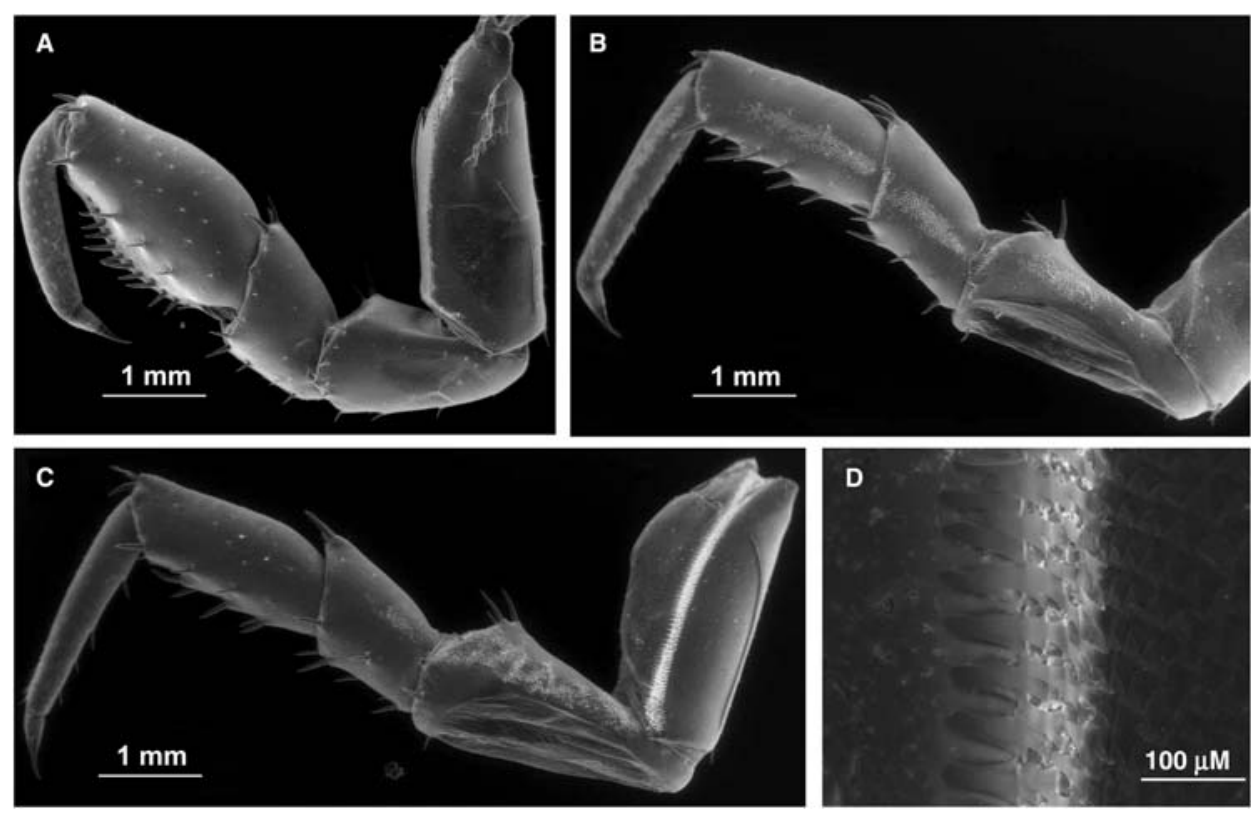

Figure 12. Trogloniscus clarkei n. sp. $O^{7}$ paratype from Dashan Dong: A: pereopod 3; B: pereopod 6; C: pereopod 7; D: scales of water conducting system on pereopod 7 basis.

\section{Remarks}

The new species differs from Trogloniscus cavernicolus, Trogloniscus hengliensis and Trogloniscus deharvengi in having a pointed frontal lobe, a penicil on the molar process of the mandibles, the basis of maxilliped distally enlarged and the anterior male pereopods subchelate. Moreover, Trogloniscus clarkei is aquatic while the three previously mentioned species are terrestrial.

\section{Trogloniscus trilobatus n. sp.}

(Figures 13-16)

Sinoniscus sp. 1; Deharveng et al. 2008: 76, tab. 1, fig. 4.

\section{Material examined}

China, Guangxi: $1 \sigma^{7}$ holotype (IZCAS), $2 \sigma^{\top} \sigma^{7}, 2$ $\rightarrow$ paratypes (MZUF), Encun Dong, Encun Village, Nandan County, leg. I. Galletti, 3.I.2002; $3 \bigcirc^{\top} \bigcirc^{7}, 2$ 우 paratypes (MZUF), Mashan Dong, 335 m, Mulun Nature Reserve, 19.V.2007, leg. L. Deharveng, A. Bedos, Y.B. Li and W.B. Xu (sample \# CHI-GX07-19-01); 1 q paratype (MZUF), same locality and date, leg. F. Bréhier (sample \# CHI-GX07-19-02); $2 \sigma^{7} \sigma^{7}, 1$ \& paratypes (MNHN), same locality; 21.V.2007, leg. F. Bréhier and Y.B. Li (sample \# CHI-GX07-2105); 1 O paratype (IZCAS), same locality, 27.X.2009, leg. M. Tian, G.F. Wei, F. Zhang and A. Clarke (sample \# CHIgx09-018); $1 \sigma^{7}$ paratype (SCAU), Dongtu Dong, Mulun Nature Reserve, 28.X.2009, leg. M. Tian and L.T. Wei (sample \# CHIgx09-019); 5 ○ ○', 3 


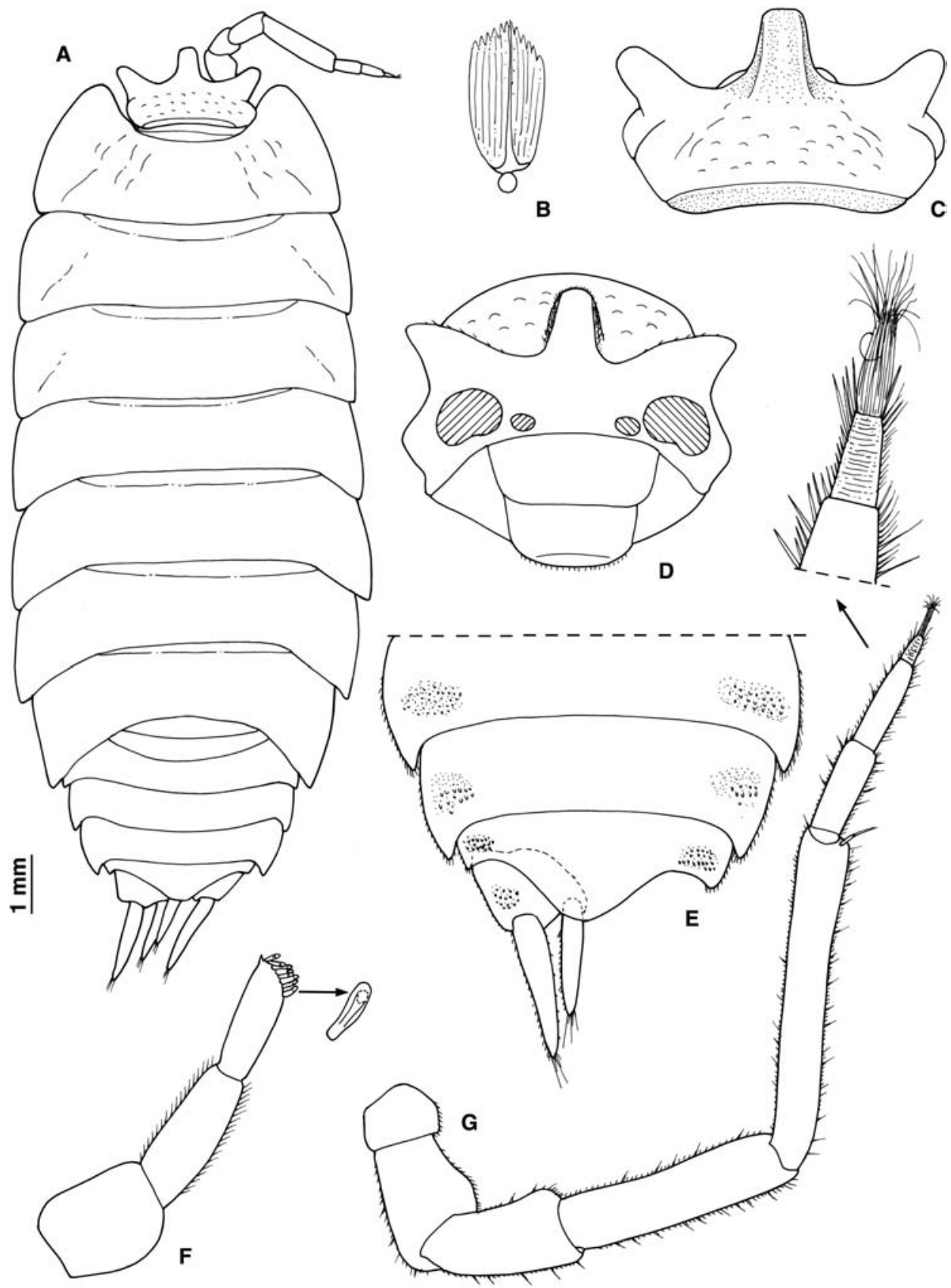

Figure 13. Trogloniscus trilobatus n. sp. + paratype from Encun Dong: A: adult specimen in dorsal view; B: dorsal scale-seta; C: cephalon, dorsal; D: cephalon, frontal. $O^{7}$ paratype from Encun Dong: E: pleonites 4 and 5, telson and left uropod; F: antennule; G: antenna. 


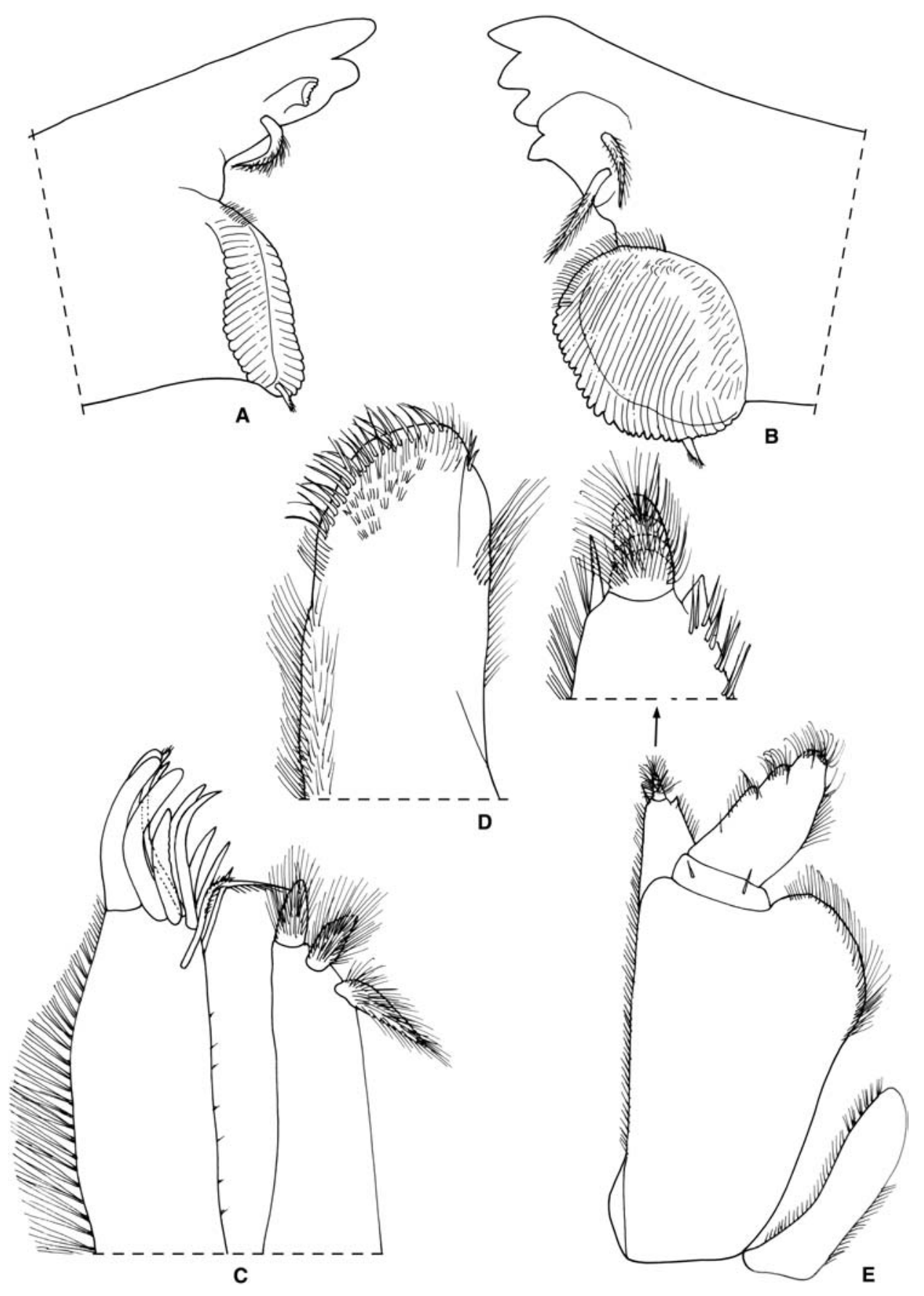

Figure 14. Trogloniscus trilobatus n. sp. $\bigcirc^{7}$ paratype from Encun Dong: A: right mandible; B: left mandible; C: maxillule; D: maxilla; E: maxilliped. 


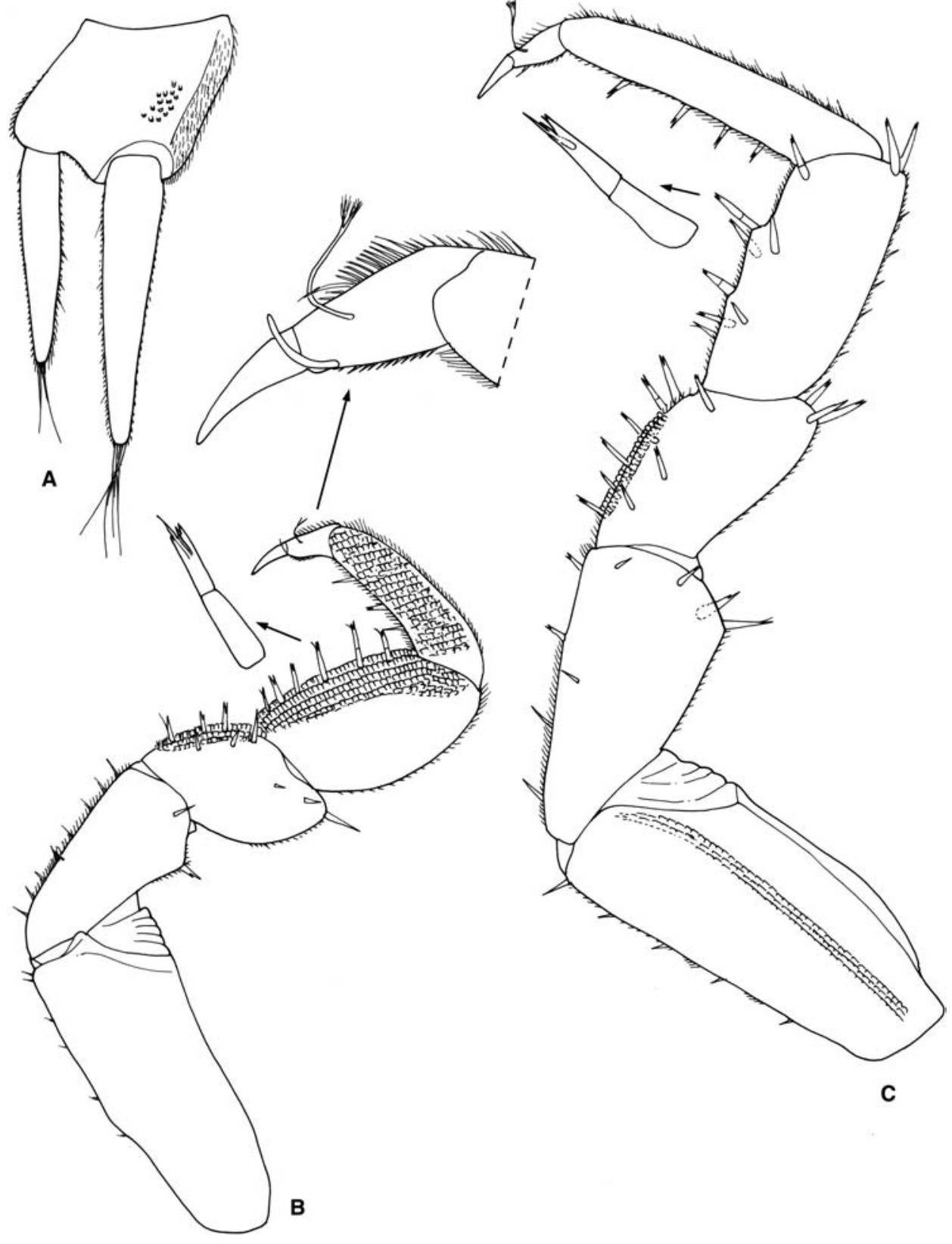

Figure 15. Trogloniscus trilobatus n. sp. $\bigcirc^{7}$ paratype from Encun Dong: A: uropod; B: pereopod 1; C: pereopod 7.

우 paratypes (IZCAS), $4 \bigcirc^{\top} \bigcirc^{\top}, 2$ $q$ paratypes (SCAU), Ganxiao Dong, Mulun Nature Reserve, 7.XI.2009, leg. M. Tian, Y.B. Li, G.F. Wei and L.T. Wei (sample \# CHIgx09087); $1 \bigcirc^{7}, 2$ 우 paratypes (SCAU), Shuiku Dong, Xianan, Huanjiang, 9.XI.2009, leg. L. Deharveng and Y.B. Li (sample \# CHIgx09-090). 


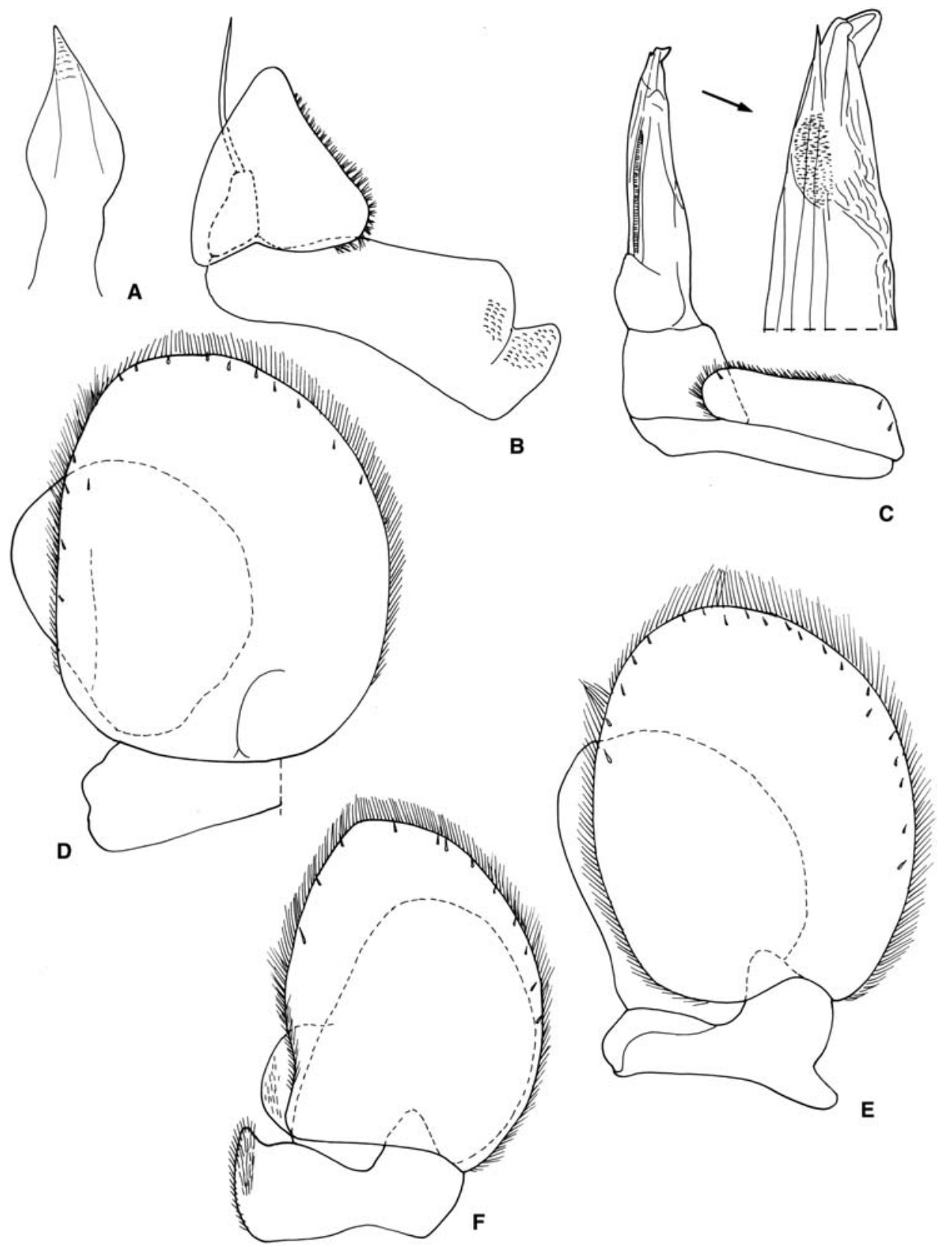

Figure 16. Trogloniscus trilobatus n. sp. $O^{7}$ paratype from Encun Dong: A: genital papilla; B: pleopod 1; C: pleopod 2; D: pleopod 3; E: pleopod 4; F: pleopod 5.

\section{Description}

Maximum dimensions: $\sigma^{\top}$ and $q, 14.5 \times 5.5 \mathrm{~mm}$. Colourless, eyes absent. Body ovoidal with pleon slightly narrower than pereon (Figure 13A). Vertex of cephalon slightly granulated, pereonites 1-3 with some oblique low ridges at sides; dorsum with sparse leaflike scale-setae (Figure 13B); a few sparse gland pores on dorsal sides of pleonite 3, large 
gland fields on dorsal sides of pleonites 4 and 5, telson and uropodal protopod (Figure 13E). Cephalon (Figure 13C,D) having large triangular lateral lobes with rounded apices and obliquely directed outwards, and a quadrangular frontal lobe, slightly excavated dorsally, directed frontwards and upwards, clearly protruding compared with the lateral lobes; rear margin of vertex raised up; frontal line along margin of lateral and frontal lobes. Pereonite 1 with postero-lateral corner at right angle and posterior margin slightly sinuous. Pereonites $2-7$ with postero-lateral corners progressively more acute; posterior margin of pereonite 7 regularly arched. Pleonites $1-3$ embedded in concavity of pereonite 7. Pleonites 3-5 with short posterior points directed backwards, triangular (Figure 13E). Telson with concave sides and broadly rounded apex (Figure 13E). Antennule elongated (Figure 13F); first article thicker than second and third; second article longer than first and third, covered with short setae; third article with a small triangular point and a row of about eight short and thickset aesthetascs at apex. Antenna (Figure 13G) with fifth article of peduncle distinctly longer than flagellum; first and second articles of flagellum subequal in length, third article much shorter. Mandibles (Figure 14A,B) with a small penicil on molar process. Maxillule (Figure 14C) endite with basal penicil distinctly longer than middle and distal penicils. Maxilla as in Figure 14D. Maxilliped (Figure 14E) with distal part of basis much wider than basal part; apical penicil of endite stout; basal article of palp with two setae. Pleopods 3-5 exopods fringed with long thin setae. Uropod (Figure 15A) with protopod about as long as wide, covered with short setae on outer margin; exopod almost twice as long as protopod; endopod shorter than exopod.

Male. Pereopods 1 and, to a lesser extent, 2 and 3 subchelate. Pereopod 1 (Figure 15B) propodus, carpus and merus with a large area covered with scales. Carpus of pereopods 2, 3 and merus of pereopods $2-7$ with scales on sternal margin. Pereopod 7 (Figure 15C) ischium with sternal margin straight. Genital papilla (Figure 16A) swollen in the middle part with pointed apex. Pleopod 1 (Figure 16B) exopod triangular, with outer margin slightly concave and fringed with thin setae; endopod with distal article flagelliform and about twice as long as basal article. Pleopod 2 (Figure 16C) exopod short, more than three times as wide as long, with medial and distal margins fringed with thin setae; endopod thickset with basal article quadrangular, distal article elongated, about three times as long as basal, with distal part having a triangular lobe obliquely directed outwards. Pleopod 3 exopod (Figure 16D) and pleopod 4 exopod (Figure 16E) ovoidal. Pleopod 5 (Figure 16F) exopod ovoidal with medial margin slightly sinuous in proximal half and a semicircular lobe on medio-basal corner.

\section{Etymology}

Greek $t r i=$ three + lobos $=$ lobe. The name refers to the cephalon with three large frontal lobes.

\section{Remarks}

In having a protruding frontal lobe, a small penicil on the molar process of the mandibles, the basis of the maxilliped distally enlarged and subchelate anterior male pereopods Trogloniscus trilobatus is similar to Trogloniscus clarkei from which it is readily distinguished by leaf-like instead of pointed dorsal scale-setae, quadrangular instead of pointed frontal lobe and male pleopod 2 endopod with a triangular lobe directed outwards at the apex. Like Trogloniscus clarkei, Trogloniscus trilobatus is also aquatic. Encun Dong is a cave located near the town of Hechi, Nandan County, Guangxi. The cave system 
belongs to a limestone area of Permian origin. At the end of the cave, large pools about $1 \mathrm{~m}$ deep formed by percolating waters are present. The specimens were found on the bottom of the larger pools where they were moving and hiding among the numerous crevices. The water temperature at the moment of collection was $13.4^{\circ} \mathrm{C}$ (I. Galletti, pers. comm.).

\section{Trogloniscus sp.}

\section{Material examined}

China, Guangxi: 1 q (MZUF), Dashan Dong (Big Mountain Cave), $670 \mathrm{~m}, 24^{\circ} 18^{\prime} 20.8^{\prime \prime} \mathrm{N}$, $107^{\circ} 00^{\prime} 47.3^{\prime \prime} \mathrm{E}$, near Dalue Village, Bama County, from a decaying bamboo pole near far end of cave, in dark zone, 20.X.2005, leg. A. Clarke.

\section{Remarks}

This specimen is similar in body shape to Trogloniscus hengliensis but its identification is not possible due to the lack of males.

\section{Discussion}

With the four new species here described, the total number of terrestrial isopods recorded from caves in southern China is now 18 (Taiti and Gruber 2008), but only the five species of Trogloniscus can be regarded as real troglobionts. The genus seems to be endemic to southern China, and it is interesting to point out that it includes both terrestrial (Trogloniscus cavernicolus, Trogloniscus hengliensis and Trogloniscus deharvengi) and aquatic species (Trogloniscus clarkei and Trogloniscus trilobatus). The two aquatic species show some peculiarities (presence of protruding frontal lobes, enlarged distal part of the maxillipedal basis and subchelate anterior male pereopods) compared with the terrestrial species, which are probably due to the adaptation to an aquatic environment. All the other characters, including the antennal flagellum and the male pleopods, are very similar in both the terrestrial and aquatic forms, and there is little doubt that they belong to the same genus. This is also confirmed by preliminary molecular data (Taiti et al. 2006).

Most of the species of Oniscidea with an aquatic or amphibious way of life belong to the Synocheta and particularly to the family Trichoniscidae. At least five species of Trichoniscidae are supposed to be truly aquatic: Typhlotrichologioides aquaticus Rioja, 1952 from the Cueva de Ojo de Aqua Grande, Vera Cruz, Mexico; Cantabroniscus primitivus Vandel, 1965 from several caves in Santander and Burgos Provinces, Spain; the crenophilic Macedonethes skopjensis Buturović, 1955 from a spring in F.Y.R. Macedonia; Macedonethes stankoi Karaman, 2003 from subterranean waters South of Skopje, F.Y.R. Macedonia and Utopioniscus kuheni Schmalfuss, 2005 from marine caves in Sardinia. According to Ortiz et al. (1999) also Brackenphiloscia vandeli Ortiz, Debrás and Lalana, 1999 from a Cuban cave is an aquatic form, and it certainly belongs to the family Trichoniscidae. Other trichoniscid forms which have an amphibian way of life have been recorded in the genera Scotoniscus Racovitza, 1908; Titanethes Schiödte, 1849; Cyphonetes Verhoeff, 1926; Alpioniscus Racovitza, 1908; Bureschia Verhoeff, 1926; Brackenridgia Ulrich, 1902; Mexiconiscus Schultz, 1964; Trichoniscoides Sars, 1899 and Balearonethes Dalens, 1977 (see Dalens 1977 and Sket 1986 for a review). The Styloniscidae, the other large family of Synocheta closely related to the Trichoniscidae, included only one species with an amphibious way of life, Thailandoniscus annae Dalens, 1989, from a cave in Thailand (Dalens 1989). Also 
among the higher Oniscidea (Crinocheta), there are taxa which occur in waters: Paradoniscus aquaticus Taiti and Ferrara, 2004 and Paradoniscus degeeri Taiti and Ferrara, 2004 (Olibrinidae) have been recorded from fresh water pools in some caves on the Socotra Archipelago, Yemen (Taiti and Ferrara 2004), and species of the genus Haloniscus Chilton, 1920, occurring in salt waters of Australian lakes, anchialine waters in New Caledonian and groundwater calcretes in Western Australia (Taiti and Humphreys 2001; Cooper et al. 2008). Contrary to what is stated by Vandel (1970) who considered the aquatic Oniscidea as primitive forms, today they are considered to be very specialized forms derived from terrestrial species and secondarily adapted to live in water (Tabacaru 1999). This is certainly true also for the two stygobitic species of Trogloniscus from southern China, as demonstrated by the presence of the water-conducting system on their pereopods 6 and 7 .

\section{Acknowledgements}

We are indebted to Dr Louis Deharveng, Paris; Prof. Mingyi Tian, Guangzhou; Dr Arthur F. Clarke, Hobart and Ms Iolanda Galletti, Ragusa, who provided us with the material dealt with in this paper and ecological information. Dr C. Giordano (CeME-CNR, Florence) and Dr I. Checcucci (ISE-CNR, Florence) are particularly acknowledged for helping us with SEM and drawings, respectively. Field trip participants and the staff of Mulun NR are thanked for having efficiently organized field trips and contributed to sampling. Surveys in the Mulun NR and surrounding karsts were sponsored by the World Bank GEF through the regional project "Guangxi integrated forestry development and conservation", and facilitated by Liu Jin and Tony Whitten.

\section{References}

Andersson A. 1960. South American terrestrial isopods in the collection of the Swedish State Museum of Natural History. Arkiv för Zoologi (2)12:537-570.

Arcangeli A. 1930. Contributo alla conoscenza del "microgenton" di Costa Rica. I. Isopodi terrestri. Bollettino del Laboratorio di Zoologia Generale e Agraria del Regio Istituto Superiore Agrario di Portici 25:1-29.

Buturović A. 1955. Isopodes nouveaux (Isop. terrestria) de Macédonie et Dalmatie. Acta Musei Macedonici Scientiarum Naturalium 3:145-157.

Chilton C. 1920. On a new isopodan genus (family Oniscidae) from Lake Corangamite, Victoria. Proceedings of the Linnean Society of New South Wales 44:723-734.

Clarke AK, 2007. Guangxi 2005 cave fauna report (China Caves Project). In: Bensley B, Campion G, Clayton M, Harrison T, Porter E, Renton A, editors. Guangxi 2005 Expedition - The 19th China Caves Project Expedition to Bama and Fengshan Counties in Guangxi Province, China. Buxton, England: British Cave Research Association; 119 p. p. 91-119.

Cooper SJB, Saint KM, Taiti S, Austin AD, Humphreys WF. 2008. Subterranean archipelago: mitochondrial DNA phylogeography of stygobitic isopods (Oniscidea: Haloniscus) from the Yilgarn region of Western Australia. Invertebrate Systematics 22:195-203.

Dalens H. 1977. Sur un nouveau genre de Trichoniscidae Balearonethes sesrodesanus n.g., n. sp. (Isopoda Oniscoïdea). Bulletin de la Société d'Histoire Naturelle de Toulouse 113:298-302.

Dalens H. 1989. Sur un nouveau genre d'oniscoide «aquatique» provenant du sud-est Asiatique: Thailandoniscus annae (Isopoda, Oniscidea, Styloniscidae). Spixiana 12:1-6.

Dana J. 1853. United States exploring expedition during the years 1838, 1839, 1840, 1841, 1842 under the Command of Charles Wilkes, U.S.N. Vol. 13, Crustacea, Part II. Isopoda. Philadelphia, PA: C. Sherman, p. 696-805, pls 46-53.

Deharveng L, Brehier F, Bedos A, Tian M, Li Y, Zhang F, Qin W, Tan X. 2008. Mulun and surrounding karsts (Guangxi) host the richest cave fauna of China. Subterranean Biology 6:75-79.

Graeve W. 1914. Die Trichoniscinen der Umgebung von Bonn. Zoologische Jahrbücher, Abteilung für Systematik, Ökologie und Geographie der Tiere 36:199-228, pls 4-6. 
Hubbard DA, Wang D. 1997. A preliminary report on some invertebrate cave fauna of China. Proceedings of XII International Congress of Speleology, La Chaux de Fonds 3:311-313.

Karaman IM. 2003. Macedonethes stankoi n. sp., a rhithral oniscidean isopod (Isopoda: Oniscidea: Trichoniscidae) from Macedonia. Organisms, Diversity and Evolution 3:239-240, and electronic supplement 8:1-15.

Kwon DH, Taiti S. 1993. Terrestrial Isopoda (Crustacea) from southern China, Macao and Hong Kong. Stuttgarter Beiträge zur Naturkunde (A, Biologie) 490:1-83.

Liu H, Wang N. 1978. The Upper Permian fish-fauna of Dzungaria Basin, Sinkiang. Memoirs of the Institute of Vertebrate Paleontology and Paleoanthropology, Academia Sinica 13(Suppl.):1-18.

Ortiz M, Debrás AG, Lalana R. 1999. Un nuevo género y una nueva especie de isópodo (Isopoda, Oniscidea) troglobio dulciacuícola, de la Isla de Cuba. Revista de Investigaciones Marinas 20:108-112.

Racovitza EG. 1908. Biospéologica. IX. Isopodes terrestres (Seconde Série). Archives de Zoologie Expérimentale et Générale 9(4):239-415, pls 4-23.

Rioja E. 1952. Estudios carcinologicos. XXIX. Un nuevo género de isópodo triconiscido de la Cueva de Ojo de Agua Grande, Paraje Nuevo, Córdoba, Ver. Anales del Instituto de Biología, Universidad de México 23:227-241.

Sars G. 1899. An account of the Crustacea of Norway. Vol. 2. Isopoda, Tribe 5. Oniscoida. Bergen: A. Cammermeyer, p. 153-192, pls 70-83.

Schiödte JC. 1849. Specimen faunae subterraneae. Bidrag til den underjordiske Fauna. Kjöbenhavn: Bianco Luno.

Schmalfuss H. 2003. World catalog of terrestrial isopods (Isopoda: Oniscidea). Stuttgarter Beiträge zur Naturkunde (A, Biologie) 654:1-341.

Schmalfuss H. 2005. Utopioniscus kuehni n. gen., n. sp. (Isopoda: Oniscidea: Synocheta) from submarine caves in Sardinia. Stuttgarter Beitrage zur Naturkunde (A, Biologie) 677:1-21.

Schmalfuss H, Erhard F. 1998. Die Land-Isopoden (Oniscidea) Griechenlands. 19. Beitrag: Gattung Cordioniscus (Styloniscidae). Stuttgarter Beiträge zur Naturkunde (A, Biologie) 582:1-20.

Schultz G. 1964. Mexiconiscus tlamayaensis, a new genus and species of terrestrial cave isopod from San Luis Potosi, Mexico. Transactions of the American Microscopical Society 83:376-380.

Schultz GA. 1995. Sinoniscus cavernicolus, a new genus and species of terrestrial isopod crustacean from a cave in China (Styloniscidae: Oniscidea). Proceedings of the Biological Society of Washington 108:201-206.

Sket B. 1986. Isopoda: Oniscidea, p. 482-485. In: Botosaneanu L, editor. Stygofauna mundi. A faunistic, distributional, and ecological synthesis of the world fauna inhabiting subterranean waters (including the marine interstitial). Leiden: E.J. Brill. VI + 740 p., 1 map.

Tabacaru I. 1999. L'adaptation à la vie aquatique d'un remarquable trichoniscide cavernicole. Cantabroniscus primitivus Vandel, et le problème de la monophylie des isopodes terrestres. Travaux de l'Institut de Spéologie "Émile Racovitza" 37-38 (1998-1999): 115-131.

Taiti S, Baratti M, Clarke A. 2006. Aquatic and terrestrial Styloniscidae (Crustacea Isopoda Oniscidea) from Chinese caves: a morphological and molecular approach, p. 59. In: Moldovan OT, editor. XVIII International Symposium of Biospeleology - 100 years of biospeleology abstracts. Cluj-Napoca: Casa Cărţii de Ştiinţă. 114 p.

Taiti S, Ferrara F. 2004. The terrestrial Isopoda (Crustacea: Oniscidea) of the Socotra Archipelago. Fauna of Arabia 20:211-325.

Taiti S, Gruber GA. 2008. Cave-dwelling terrestrial isopods from southern China (Crustacea, Isopoda, Oniscidea), with descriptions of four new species. In: Latella L., Zorzin R., editors. Research in South China karsts. Memorie del Museo Civico di Storia Naturale di Verona, Monografie Naturalistiche 3:101-123.

Taiti S, Humphreys WF. 2001. New aquatic Oniscidea (Crustacea: Isopoda) from groundwater calcretes of Western Australia. Records of the Western Australian Museum 64(Suppl.):133-151.

Ulrich C. 1902. A contribution to the subterranean fauna of Texas. Transactions of the American Microscopical Society 23:83-100.

Vandel A. 1952. Les trichoniscides (Crustacés - Isopodes) de l'hémisphère austral. Leur place systématique. Leur intérêt biogéographique. Mémoires du Muséum National d'Histoire Naturelle, Paris (A, Zoologie) 6:1-116. 
Vandel A. 1965. Sur l'existence d'oniscoïdes très primitifs menant une vie aquatique et sur le polyphylétisme des isopodes terrestres. Annales de Spéléologie 20:489-518.

Vandel A. 1970. Un troisième oniscoïde cavernicole menant une vie aquatique: Mexiconiscus laevis (Rioja). Annales de Spéléologie 25:161-171.

Verhoeff KW. 1926. Über Isopoden der Balkanhalbinsel, gesammelt von Herrn D-r. I. Buresch. Zugleich 31. Isopoden-Aufsatz. Mitteilungen der Bulgarischen Entomologischen Gesellschaft in Sofia 3:135-158. 